\title{
Optical Absorption Measurement of Synthesized ZnO using Ultra Violet-Visible Spectrophotometer
}

\author{
Nagla El Badri Mohammed Saeed EI Badri ${ }^{1}$, Kamal Mahir Sulieman² \\ ${ }^{1}$ Physics Department, College of Applied and Industrial, Sciences, University of Bahri, Sudan \\ ${ }^{2}$ Physics Department, Faculty of Education, AL-Zeem Al-Azhari University
}

\begin{abstract}
Zinc oxide (ZnO) is characterized by its unique electrical and optical properties. It is a future substance and promising compound which can be applied in different structures and used to fabricate different devices. The main objective of this work is to investigate the optical properties of $\mathrm{ZnO}$ annealed at $1000^{\circ} \mathrm{C}$ in muffle furnace for 3,6 and 9 hours. The annealed samples were Zinc, Zinc sulphide and zinc sulphate, where commercial zinc oxide was used as a control sample. The oxidized ZnO samples were dispersed in an absolute ethyl alcohol with ultrasonic wave. The excitonic peaks of the prepared ZnO samples appeared at 229.99 and 207.51 nm. The excitonic absorption of $\mathrm{Zn}$ samples annealed at $1000^{\circ} \mathrm{C}$ for 3 , 6, and $9 \mathrm{~h}$ represented the strongest and sharp peaks around 229.99 $n m$. The absorbance values spectra of $\mathrm{ZnSO4}$ samples annealed at $1000^{\circ} \mathrm{C}$ for $3 \mathrm{~h}$ represented a higher value of 0.89 au as compared with the control and other samples. These results indicated that high temperature for a long time will improve the electrical and optical properties of $\mathrm{ZnO}$ samples obtained from different sources.
\end{abstract}

Keywords: Absorbtivity of ZnO, UV-Vis spectrophotometer, absorbance value, ultrasonic wave, Optical absorbance.

\section{Introduction}

Semiconductors materials are characterized by the small band group ranging from 0.2 to $2.5 \mathrm{eV}$, which is quite small as compared to that of insulators $(6.0 \mathrm{eV})$. This character determine the wavelength of radiation which can be emitted or absorbed by the semiconductors and hence help in application in different devices such as light emitting diodes (LEDs) and laser. $\mathrm{ZnO}$ exhibits semiconducting, piezoelectric or pyroelectric properties. Due to this, $\mathrm{ZnO}$ can be used in many devices, electrochemical applications......etc [1]. It is characterized by strong luminescence in the green-white region of the spectrum, therefore it can be used as suitable material for phosphor application. The emission spectrum have a peak at $495 \mathrm{~nm}$ and a very broad half-width of $0.4 \mathrm{eV}$. Also it is a biofriendly oxide semiconductor and an inexpensive luminescent material. It plays a role in photo-decompose harmful bacteria [2] and protects skin and eyes from UV radiation without causing irradiation [3]. There is no any evidence that $\mathrm{ZnO}$ is carcinogenic or genotoxic or produce toxins in humans [4]. Due to all these properties, $\mathrm{ZnO}$ is a promising material in the future to be used in different fields.

The UV-VIS uses two light sources, deuterium lamb for ultraviolet light, and tungsten light which is designed to verify the ultraviolet and visible light protection level accurately and consistently. As reported by [5] $\mathrm{ZnO}$ absorbed only in the UV region because of its large bandwidth of $3.2 \mathrm{eV}(\lambda=380 \mathrm{~nm})$. $\mathrm{ZnO}$ exhibited two emission bands, ultraviolet (UV) emission band and another in the green region[6]. Also they found that the intensity of the UV peak remained the same, while the intensity of the visible peak increase with the increase in the annealing temperature. The nano-linear absorption coefficient increased from $2.9 \times 10^{-6}$ to $1.1 \times 10^{-4} \mathrm{~m} / \mathrm{W}$ when the annealing temperature increased from 300 to $105^{\circ} \mathrm{C}$.
However the presence of defects (vacancies, interstitial, and antisites) and impurities will play an important role in improvement of electrical and optical properties of $\mathrm{ZnO}$ [7]. Zinc interstitial has a high formation energies and low diffusion barriers [8]. They are thus unlikely to be incorporated into stability of $\mathrm{ZnO}$ structure. Oxygen vacancies lowest the formation energies and its vacancy is deep rather than shallow donor in the $\mathrm{ZnO}$ structure.

Today improving of $\mathrm{ZnO}$ properties can be achieved by using different methods such as doping and exposing of $\mathrm{Zn}$ and its compounds to heat treatment at different temperatures. The main objective of this work is the investigation of the optical absorption and absorbance value of synthesized $\mathrm{ZnO}$ samples after annealing at $1000^{\circ} \mathrm{C}$ for different time intervals using Ultra Violet-Visible Spectrophotometer.

\section{Material and Methods}

\subsection{Collection of Samples}

The samples used were $\mathrm{Zn}$ (65.38) powder material, zinc sulphate $(\mathrm{ZnSO} 4)$, zinc sulphide $(\mathrm{ZnS})$ and commercial zinc oxide $(\mathrm{ZnO})$ M.W. 81.38, all are manufactured by British Drug Houses LTD. All samples were obtained from Food Science and Technology and Soil Departments, Faculty of Agriculture, University of Khartoum, and Chemistry Department, Collage of Science and Technology, Sudan University.

\subsection{Samples Preparation}

Firstly, 3 grams of each investigated $\mathrm{ZnO}$ samples were put in a crucible and annealed at $1000^{\circ} \mathrm{C}$ in a muffle furnace (England, Maximum Temperature $1200^{\circ} \mathrm{C}$ ) for 3, 6 and 9 hours to obtain the oxidized form of $\mathrm{ZnO}$ compounds, while the commercial $\mathrm{ZnO}$ sample is not subjected to heat treatment and used as a control. 


\section{International Journal of Science and Research (IJSR) \\ ISSN (Online): 2319-7064}

Index Copernicus Value (2013): 6.14 | Impact Factor (2014): 5.611

A certain weight $(0.1 \mathrm{~g})$ of oxidized samples $(\mathrm{Zn}, \mathrm{ZnS}$, and $\mathrm{ZnSO} 4)$ and commercial zinc oxide $(\mathrm{ZnO})$ as a control were dissolved in an absolute ethyl alcohol (Media Laboratories, India) by using altrasonic apparatus (BANDELIN, SONOREX, NO, 301, 0003321, 012, Germany, 2007). The optical absorption spectra of synthesized $\mathrm{ZnO}$ samples was measured by UV-VIS spectrophotometer in the range of 190-1100 nm. Then each sample solution (dissolved ZnO) was held in cuvate quartz with optically flat faces held perpendicular to the radiation beam. The control cell was calibrated at range of absorbitivity from 0 to $10^{6}$. Values above $10^{6}$ are termed high-intensity absorption, while the values below $10^{3}$ are low-intensity absorption. Transitions have absortptivities in the range from 0 to 1000 are neglected. The results were recorded as a plot of absorbance versus wavelength.

\section{Results and Dissections}

The results of the $\mathrm{ZnO}$ samples obtained from $\mathrm{Zn}$ annealed at $1000^{\circ} \mathrm{C}$ for $3,6,9$ hours were showed in Fig. 1, 2, and 3, while for the samples obtained from $\mathrm{ZnS}$ were showed in Fig. 4, 5, and 6. As for the samples obtained from $\mathrm{ZnSO} 4$ were presented in Fig. 7, 8, 9, and for the commercial $\mathrm{ZnO}$ showed in Fig. 10. It can be seen that the excitonic peaks of the prepared $\mathrm{ZnO}$ samples appeared at 229.99 and 207.51 $\mathrm{nm}$. The excitonic absorption of oxidized $\mathrm{Zn}$ samples annealed at $1000^{\circ} \mathrm{C}$ for 3,6 , and $9 \mathrm{~h}$ represented the strongest and sharp peaks around $229.99 \mathrm{~nm}$ followed by control sample (commercial $\mathrm{ZnO}$ sample) around 227.54 $\mathrm{nm}$, and then followed by oxidized samples of $\mathrm{ZnS}$ around $225.10 \mathrm{~nm}$ and $\mathrm{ZnSO} 4$ around $224.61 \mathrm{~nm}$. Similar results were obtained by [9] who stated that thin films deposited at and below $300^{\circ} \mathrm{C}$ did not absorb light in the $300-1100 \mathrm{~nm}$ with only slight absorption between 200 and $300 \mathrm{~nm}$. The absorption between or at shorter wavelength was somewhat improved for film deposited at $350^{\circ} \mathrm{C}$ and above as well as for films annealed at $600^{\circ} \mathrm{C}-1000^{\circ} \mathrm{C}$. Also the stated that the suspension of the $\mathrm{ZnO}$ nanoparticles showed excellent UVabsorption capacity and high transparency in visible light. This result suggest that $\mathrm{ZnO}$ particles are well-dispersed maintaining high stability with less agglomeration, which in turn can reduce of visible light since $\mathrm{ZnO}$ has band-gap energy of $\sim 3.3 \mathrm{eV}$. The absorption behavior of $\mathrm{ZnO}$ suspension is predominate on the valence band to conduction band transition. $\mathrm{ZnO}$ has good absorption for light in the wavelength in the range of 220-350 $\mathrm{nm}$ [10]. The absorption of synthesis Zno was at 373 and $379 \mathrm{~nm}$ as the annealing temperature increased from $300^{\circ} \mathrm{C}$ to $500^{\circ} \mathrm{C}$ [11].

Another study revealed that the absorption ranges of $\mathrm{ZnO}$ nanorods obtained from a low power DC thermal plasma reactor were about $300 \mathrm{~nm}$ and $340 \mathrm{~nm}$ as the peak at $311 \mathrm{~nm}$, which was classified as short UV. Also they claimed that the prepared $\mathrm{ZnO}$ nano-rods exhibited high UV-blocking capacity which is useful to be applied in cosmetic field as sun block [12]. The absorption spectrum at shorter wavelength in this study may attributed to the formation of small particles size of $\mathrm{ZnO}$ samples. The absorption spectra at wavelength $<370 \mathrm{~nm}$ indicated the smaller size of $\mathrm{ZnO}$ formed [13]. Another study was carried out by [14] who reported that the particles size will affect the absorption of spectra gradually shifted from 370 to 380 due to the increase of the size of particles from 20 to $40 \mathrm{~nm}$, and the shift absorption edge with the decreasing of crystallite particles was attributed to the light quantum confinement. As pointed by [15], the sharp excitionic peak in the absorption spectra at $300^{\circ} \mathrm{C}$

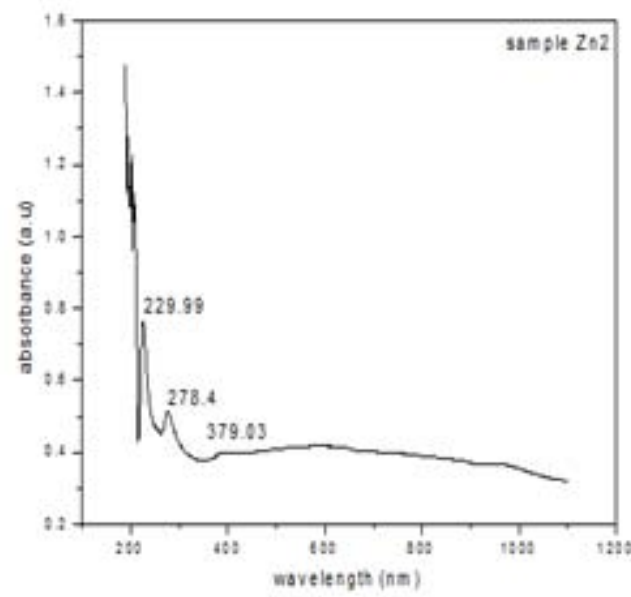

Figure 1: UV analysis of $\mathrm{ZnO}$ obtained from $\mathrm{Zn}$ annealed at $1000^{\circ} \mathrm{C}$ for 3 hours

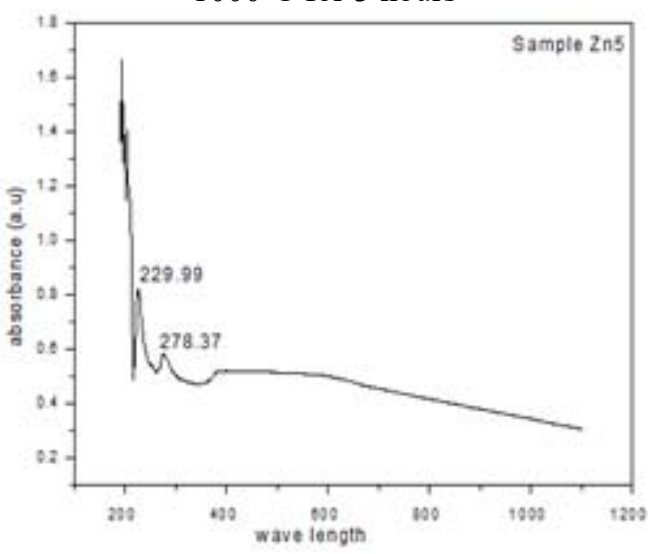

Figure 2: UV analysis of $\mathrm{ZnO}$ obtained from $\mathrm{Zn}$ annealed at $1000^{\circ} \mathrm{C}$ for 6 hours

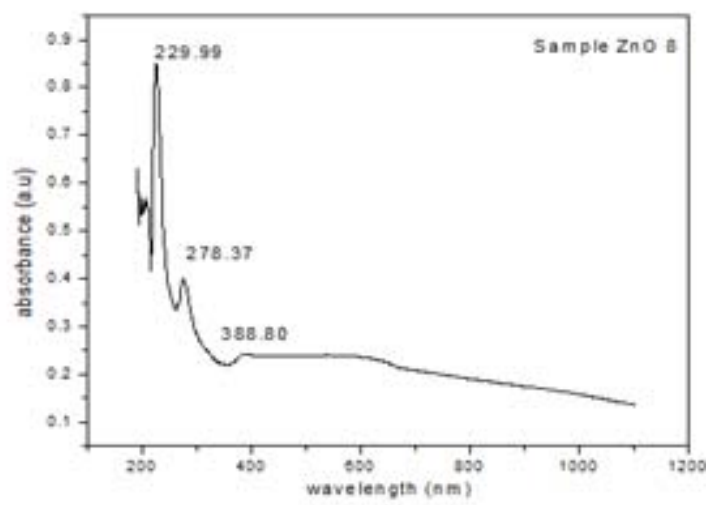

Figure 3: $\mathrm{UV}$ analysis of $\mathrm{ZnO}$ obtained from $\mathrm{Zn}$ annealed at $1000^{\circ} \mathrm{C}$ for 9 hours 


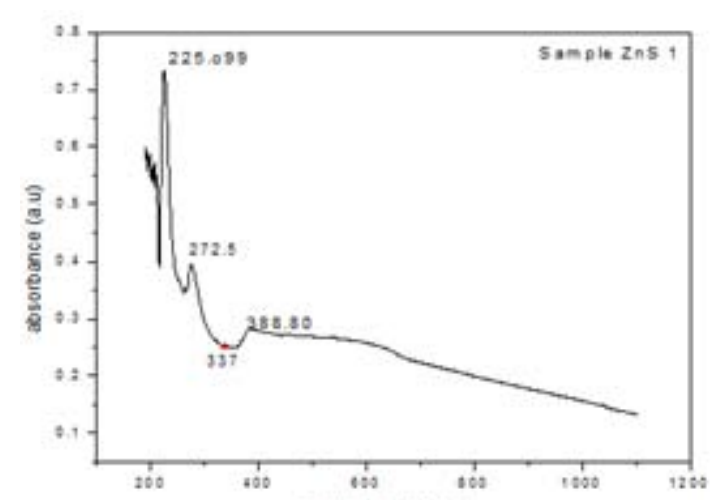

Figure 4: $\mathrm{UV}$ analysis of $\mathrm{ZnO}$ obtained from $\mathrm{ZnS}$ annealed at $1000^{\circ} \mathrm{C}$ for 3 hours

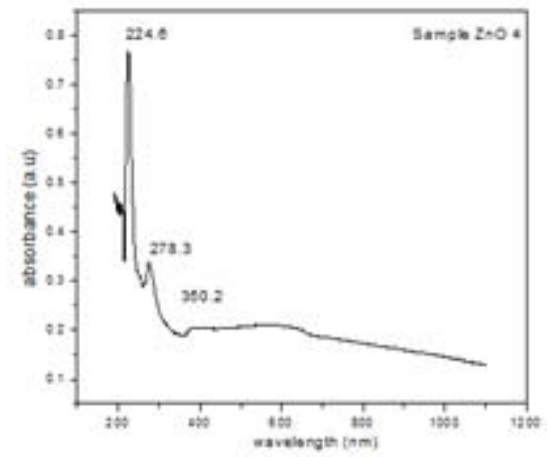

Figure 5: UV analysis of $\mathrm{ZnO}$ obtained from $\mathrm{ZnS}$ annealed at $1000^{\circ} \mathrm{C}$ for 6 hours

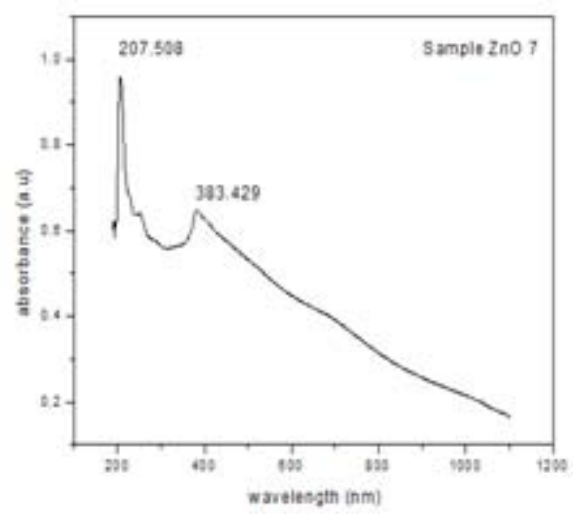

Figure 6: $\mathrm{UV}$ analysis of $\mathrm{ZnO}$ obtained from $\mathrm{ZnS}$ annealed at $1000^{\circ} \mathrm{C}$ for 9 hours

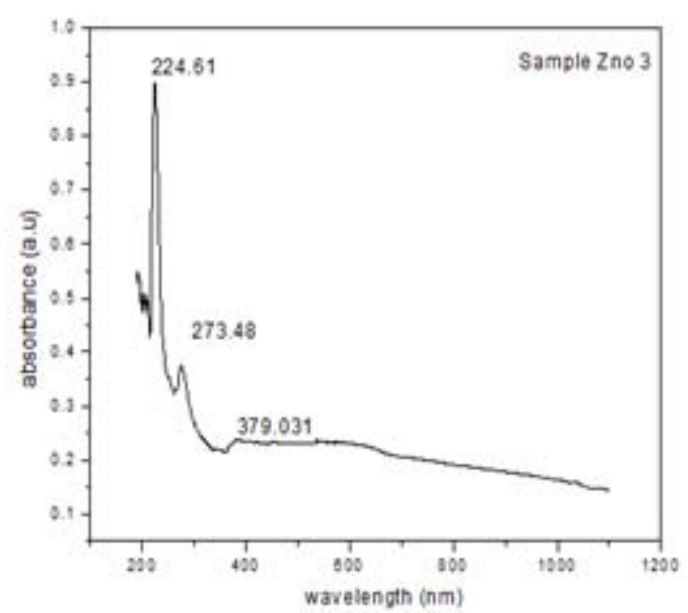

Figure 7: UV analysis of $\mathrm{ZnO}$ obtained from $\mathrm{ZnSO}_{4}$ annealed at $1000^{\circ} \mathrm{C}$ for 3 hours

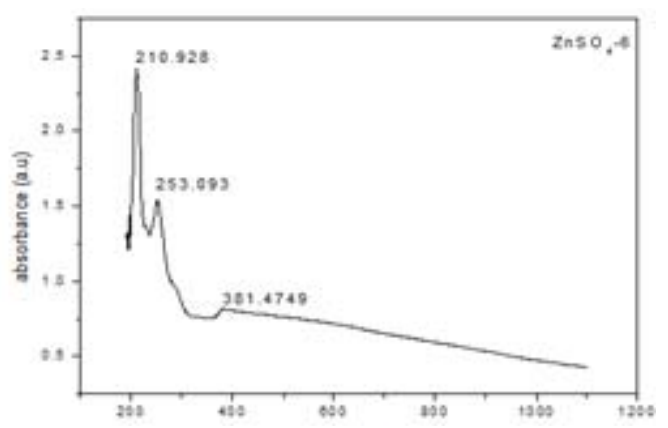

Figure 8: $\mathrm{UV}$ analysis of $\mathrm{ZnO}$ obtained from $\mathrm{ZnSO}_{4}$ annealed at $1000^{\circ} \mathrm{C}$ for 6 hours

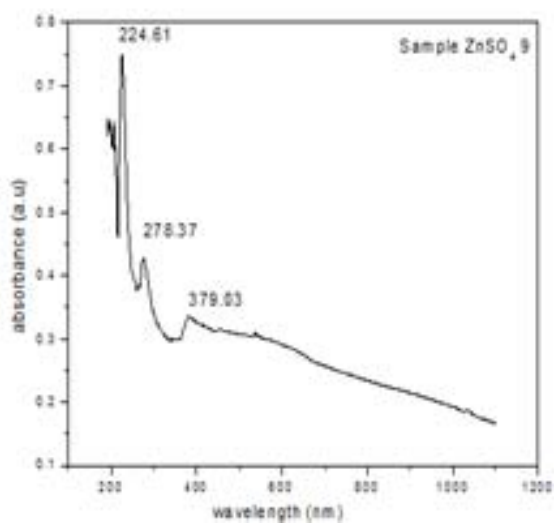

Figure 9: UV analysis of $\mathrm{ZnO}$ obtained from $\mathrm{ZnSO}_{4}$ annealed at $1000^{\circ} \mathrm{C}$ for 9 hours

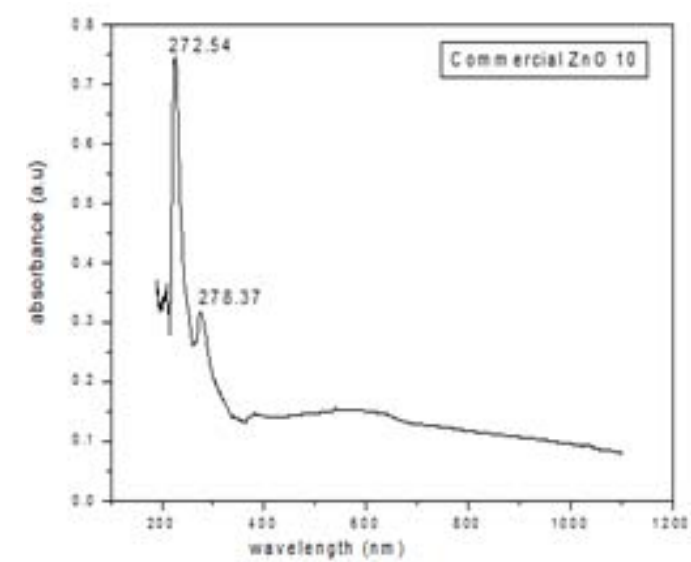

Figure 10: UV analysis of commercial $\mathrm{ZnO}$ sample

indicative of small size distribution of nanocrystals in the sample and a broadening of peaks at higher temperature clearly indicates the increase in size nanocrystals with increases of temperature. The absorbance values spectra of $\mathrm{ZnSO} 4$ samples annealed at $1000^{\circ} \mathrm{C}$ for $3 \mathrm{~h}$ represented a higher value of 0.89 a.u than that of commercial $\mathrm{ZnO}(0.76$ a.u), followed by $\mathrm{Zn}$ sample $(0.77 \mathrm{a} . \mathrm{u})$ and then $\mathrm{ZnS}(0.73$ a.u) as presented in Figs. 7, 10, 1 and 4. Similar trend was observed for the samples annealed at $1000^{\circ} \mathrm{C}$ for $6 \mathrm{~h}$, whereas $\mathrm{ZnSO} 4$ showed a high of 2.40 a.u followed by $\mathrm{Zn}$ with value of 0.80 a.u and $\mathrm{ZnS}$ of 0.76 a.u when compared to the commercial $\mathrm{ZnO}$ sample ( Figs. 8, 2, 5 and 10).

As for the samples annealed at $1000^{\circ} \mathrm{C}$ for 9 hours, $\mathrm{ZnS}$ sample showed a high value of 0.96 a.u followed by $\mathrm{Zn}$ with value of 0.86 a.u and $\mathrm{ZnSO} 4$ with a value of 0.76 a.u as compared to the commercial $\mathrm{ZnO}$ (Figs. 6, 3, 9 and 10). The high value of absorbance obtained in this study may be 


\section{International Journal of Science and Research (IJSR) ISSN (Online): 2319-7064 \\ Index Copernicus Value (2013): 6.14 | Impact Factor (2014): 5.611}

attributed to high temperature of annealing for along time which improves the electrical and optical properties [16][17] and also may be due to the decrease in crystalinity. Similar study was conducted [18] who reported that the absorption increases as sintering temperature rises from $400^{\circ} \mathrm{C}$ to $600^{\circ} \mathrm{C}$. The rise in absorption observed on increasing sintering temperature may be referred to the decrease in crystanillity, while stoichiometry has seemingly remained unaffected by variations in sintering temperature [19]. It was observed that the absorbance of $\mathrm{ZnSO} 4$ annealed at $1000^{\circ} \mathrm{C}$ for $6 \mathrm{~h}$ in this study was increased to 2.40 a.u and then decreased to 0.76 a.u after $9 \mathrm{~h}$ annealing. Similar study revealed that the absorbance of $\mathrm{ZnO}$ samples obtained from $\mathrm{ZnSO} 4 . \mathrm{HO} 2$ increased when the temperature increased from $300^{\circ} \mathrm{C}$ to $500^{\circ} \mathrm{C}$ and then decreased at $800^{\circ} \mathrm{C}$ [15]. The decrease in optical absorption may be due to the improvement in crystalinity and/or stoichiometry [18]. A broadening of $\mathrm{ZnO}$ sample peak obtained from $\mathrm{ZnS}$ and $\mathrm{ZnSO} 4$ annealed at $1000^{\circ} \mathrm{C}$ for 9 and $6 \mathrm{~h}$ were observed as shown in Fig. 6 and 8 respectively. This result claimed that there is an increase of particles size at high temperature for along time [20]. The broadening of absorption edge at higher sintering temperature $\left(600^{\circ} \mathrm{C}\right)$ may be due to the increase of disorder in semiconductor films and leads to the appearance of localized electron or/ hole state [19]. The whole results explain that the synthesized or oxidized $\mathrm{ZnO}$ samples from different sources exhibited a good absorbance behavior and ensures the ability of $\mathrm{ZnO}$ to absorb short UV and can be used in different application.

\section{References}

[1] A. A. Dakhel, and El-Hilo. Ferromagnetic nanocrystalline Gd-doped $\mathrm{ZnO}$ powder synthesis by copreciptation. Journal of Applied Physics. 107, 123905, 2010.

[2] A. Sirelkhatim, Sh. Mahmud, A. Aseeni, N. A. M. Kaus, L. Ch. Ann, S. Kh. M. Bakhori, H. Hasan, and D. Mohamad. Review on Zinc Oxide Nanoparticles: Antimicrobial Activity. Nano-Micro Lette, 7 (3): 219242, 2015.DOI 10.1007/s40820-015-0040-x.

[3] Z.L. Wang. Zinc oxide nanostructures: growth, properties and application. Journal of Phys. Condensed Matter. 16: R829- R858. 2004.

[4] E. U. Umicore. Classification -Directive 67/548/EEC. [citied 22/10/2010] Available from: http:www.zincchemicals.umicore.com/zcProducts/fineZ incPowders/EHS/classification.htm,2010.

[5] W. F. Mohamad, A. A. Hajarand A. N.Saleh. Effect of oxide layers and metals on photoelectric and optical properties of Schottky barrier photodetector. Renew Energy.31(10), 1493-503, 2006.

[6] I. Litty, D. Ambika, V. Kumar, V. P. N. Namoori, and Radhakrishan. Effect of annealing on the spectral and nonlinear optical characteristics of thin films of nanoZnO. Journal of Applied Physics. 104 (3): 03318033118-9. Doi. 10.1063/1.2949400 source: 1EEEexplore, 2008.

[7] D. Sridevi, and K. V. Rajendran Synthesis and optical characteristics of $\mathrm{ZnO}$ nanocrystal. Bull. Matter. Sci. 32 (2): 165-168. Indian Academy of Science, 2009.
[8] F. Tuomiso, K. Saarinen, D. C. Look, and G. C. Farlow,. Introduction and recovery of point defects in electron-irradiated ZnO. Phys. Rev. B. 72085206, 2005.

[9] N. Golego, S. A. Studenikin, and M. Cocivera. Properties of Dielectric Thin Film BaTiO3 prepared by Spray Pyrolysis. Chem. Mate, 2000.

[10] S. J. Chen, Y. C. Liu, J. G. Ma, Y. M.Lu, J. Y. Zhang, D. Z. Shen and X. W Fan. Effect of thermal treatment on the properties of $\mathrm{ZnO}$ films deposited on $\mathrm{MgO}$ bufferd Si substrate. Journal of Crystal Growth. 254: 86-9, 2003.

[11]X.. Zhang, J. Oin, Y. Xue, P. Yu, B. Zhang, L. Wang, and R. Liu. Effect of aspect ratio and surface defects on the photocatalytic activity of $\mathrm{ZnO}$ nanorods. 4596. doi:101038/srep04596, 2014.

[12] S. Ubaidillah, E.J. Wibawa, P. Bayu, P. and Agus Physical Characteristics of $\mathrm{ZnO}$ nanorods synthesized by low power DC thermal plasma, 2012.

[13] Skoog et al.. "Principles of Instrumental Analysis". $6^{\text {th }}$ edition. Thomason Brooks. Pp. 169-173, 2007.

[14] T. Olorunyolemi, Y. Birnboim, O. C. Carmel, J. R. Wilson, and I. K. Lloyd. Investigation of Structural and Optical Properties of Nano-crystaline $\mathrm{ZnO}$ J. Am. Ceram. Soc. 84, 2002.

[15] R. Chauhan, A. Kumar, and R. Chauhanry. Structure and Optical Properties of Zn1-xN1Xo Nanonstructures by Coperciptation Method. Journal of Optoelectronics and Biomedical Materials. 3,Issue, pp. 17-23, 2011.

[16]Ch. Sheng-Yuan, W. Water, and L. Jih-Tsang, Influence of postdeposition annealing on the properties of $\mathrm{ZnO}$ films prepared by $\mathrm{RF}$ magnetron sputtering. Journal of European Ceramic Society. 23, 1593-1598, 2003.

[17]X. Gu, Sh. Sabuktaging, A. Take, D. Johnstonc, H. Mórkoc, B. Nemeth, and J. NOUSE. Effect of thermal treatment on $\mathrm{ZnO}$ substrate for epitaxial growth. Journal of Materials Science: Materials in Electronics. 15: $373-$ 378,2004

[18] V. Diaoued, V. H. Phong, S. Badilescu, P .V. Ashrit, F. E. Girourard, and V.V. Truong,. Thin Solid Films. 293,108, 1997.

[19] B. D. Ahn, S.H. OH, C. H. Lee, G. H. Kim, H. J. Kim, and S.Y. Lee. (2007). Influence of thermal annealing ambient on Ga-doped $\mathrm{ZnO}$ thin film.J. Cryst. Growth, 309, 128.

[20] D. Chauhan, V.R. Stasangi, S. Dass, and R. Shrivastav, Bull. Mater. SCi.29-709, 2006.

\section{Author Profile}

Nagla Nagla El Badri Mohammed Saeed El Badri received the B. Sc degree in Physics/ Mathematics from Upper Nile UniversitySudan in 2005 and M.Sc. degree in Solid States from AL-Zeem AlAzhari University - Sudan in 2014. During 2005-2011, she taught as teaching assistant at Upper Nile University and as a teacher of physics at higher secondary schools at Upper Nile State, South Sudan. Teaching assistant at Bahri University- Department of physics from 2011-2013. Now she is a lecturer in physics department, College of Applied and Industrial Sciences. Bahri University, Sudan.

Kamal Mahir Sulieman Associated professor at physics Department, Faculty of Education, AL-Zeem Al-Azhari University. Now he joined Hael University Saudi Arabia. 